\title{
SPORTS CLUBS AS LEARNING ORGANIZATIONS - POLISH MODEL
}

\author{
ANNA DRAB-KUROWSKA, ${ }^{1}$ PAWEŁ KUŹBIK ${ }^{2}$ \\ ${ }^{1}$ University of Szczecin, POLAND \\ e-mail: anna.drab@wzieu.pl \\ 2 University of $\mathrm{Lodz}$, POLAND \\ e-mail: pawel.kuzbik@uni.lodz.pl
}

RECEIVED
ACCEPTED
JEL
CLASSIFICATION

KEYWORDS

ABSTRACT
4 December 2017

5 January 2018

L83, M14

learning organization, knowledge based economy, information society, management

Sports clubs in Poland, wanting to develop and become more and more competitive, cannot be based only on material resources. The past and present of this type of organization clearly show that this chosen direction is fatal. Contemporary, modern sports organizations must learn to draw on intangible resources such as knowledge gathered among employees and management, resources and technological capabilities, the experience of the whole organization or specific partners - stakeholders ready to support the club at every organizational level. The aim of the article is an attempt to recognize the idea of a learning organization in the context of functioning sports clubs in Poland.

\section{Introduction}

Contemporary economy, called the "knowledge-based economy" (KBE), or the New Economy creates a new economic reality, which is why it is necessary to undertake far-reaching changes to adapt to functioning in the conditions of globalization, high level of competition resulting from the creation of cooperative systems, intense innovation processes, and the rapid flow of information and the development of knowledge resources. 
For contemporary organizations that want to survive and have a chance for further development, knowledge should be a key strategic resource (Budziewicz-Guźlecka, Drab-Kurowska, 2009, p. 39). Observing the activities of the organization, it can be clearly seen that they are not always sufficient. The aim of the article is an attempt to recognize the idea of a learning organization in the context of functioning sports clubs in Poland. The article presents the following research hypothesis - Intensification of activities of sports clubs in the area of development of a learning organization will increase the effectiveness of their functioning. In reference to the assumed goal and the hypothesis adopted in the article, the following research question was posed - which areas of sports clubs activity should be supported in order to strengthen their development towards a learning organization? In an attempt to answer the question, the article first referred to the essence and specificity of a learning organization. Next, the specificity of sports clubs was presented. In contrast, a key component of the article is to propose a model that will allow for the development of the sports club as a learning organization.

\section{The essence of a learning oryanization}

When attempting to define the concept of a learning organization, it should be pointed out that it is treated as one of many contemporary conceptual models of organizations presenting mechanisms, structures, principles and instruments of action that allow economic entities, after their implementation, to adapt to the environment, flexibly transform the organization in the event of changes, and effectively develop business activities (Mikuła, 2017 p. 25). The concept of a learning organization is not a new concept. Opinions emerge, according to which this concept is almost 30 years old - and some see its beginning in the middle of the 20th century (Olszewska, 2013, pp. 17-19, Burke, Noumair, 2015, pp. 13-13). It needs to be emphasized that the idea is currently most upto-date. The active use of knowledge is based on its continuous development. Organizations must be focused on constant innovation, on a continuous systematic change of operating techniques (Budziewicz-Guźlecka, 2014, p. 12). Business entities, including sports clubs, in a natural way, become learning organizations which are the subject of considerations in this article. Referring to the term of the learning organization, reference should be made to definitions that emphasize its specificity. Seebacher identifies a learning organization as a company in which people constantly expand their ability to create the desired results. New and expansive models of thinking are the main motive for development, where collective aspirations are a free creator and where people constantly learn how to learn (Seebacher, 2002, p. 144.) Sitko-Lutek indicates the non-accidental nature of acquired information. She defines it as an "organization" that consciously acquires new knowledge, skills and competencies, as well as shapes desirable values and attitudes. In addition, the organization learns both thanks to the relationships that take place within it, and thanks to the environment (customers, suppliers, competitors). This phenomenon occurs at all levels of the organization, in relation to both individuals and teams. Improvement of the organization consists in enabling it to function efficiently not only in the present but also in the future (Sitko-Lutek, 2009, p. 75). Another definition shifts the focus to employees, recognizing that all employees see themselves as learners on behalf of the company and take responsibility for their personal development to keep up with the pace of change. In this definition, the traditional relationship between the supervisor and the subordinate has been replaced by self-management, and the employees are proactive and take action on their own initiative. It should be emphasized that the top-down management is limited and the scope of supervision is reduced. Employees, who take responsibility for personal learning and rationalization of work, have room for improvement and have an impact on business (Kaczmarek, 2012, p. 467). 
As it can be seen, the definitions of the learning organization and its features particularly emphasize the learning processes of people. In practice, the key to understanding the idea and creating a learning organization is to master and consciously use the processes of organizational learning. These organizations gather experiences, formulate conclusions based on them and store them in the warehouses of organizational knowledge (Olszewska, 2013, p. 16).

The core of a learning organization is the lifelong learning program. There are five pillars that are considered crucial for each organization (Senge 2016, p. 6):

- personal mastery,

- psychological models,

- a shared vision,

- team learning,

- system thinking.

Summing up the considerations concerning the essence of the learning organization, it is clearly visible that this is a key phenomenon for the development of every economy and entities operating on the market. It is necessary to undertake multidirectional activities, but the common area is knowledge and the human factor, which are the core of the learning organization.

\section{The specificity of the sports club environnment}

In order to understand the specificity of the learning organization in the context of sports clubs and the role of managerial staff in this area, it is necessary to clearly indicate a specificity that distinguishes this type of organization from those that are considered traditional. It should be agreed that sports organizations such as sports clubs have the overriding objective of functioning which is creating conditions for playing sports and organizing sporting events (Szwarc, 2000, pp. 23-25), but nowadays, this understanding of the sports club is insufficient. Professional clubs participating in sports competition at the highest league/competitive levels are subject to similar rules of the market economy, as are organizations in many other areas of life (Waśkowski, 2011, p. 253).

Although sports clubs must also follow the principles of the economic calculation, build effective structures, take care of clients, search for new techniques and management methods, the sport area is so specific and clearly different from traditional economic organizations (Kuźbik, 2014, p. 197), that it is a necessity for such clubs to become the learning and, consequently, intelligent organizations; organizations that will be able to react quickly to changing conditions in the environment, not only considering sports but also economic and social issues. And finally, organizations that will develop improve and become more competitive, ready to meet the high expectations of all stakeholder groups.

One of the most important interest groups is supporters who are keenly interested in the functioning of a given club (organization), who often emphasize (in various places, not only at the stadium) their deep attachment to club colours which have a strong and extraordinary impact on the functioning of a given club. Therefore, it is hard to disagree that they also become a source of extremely valuable information that not only can but also should translate into the club's proper knowledge, allowing for upgrading organizational competencies. Therefore, it is crucial to skilfully build a relationship between this group and the managerial staff and the entire organization, because no club in the world can afford, not to use such a characteristic network of connections, relationships and 
knowledge at the same time (Kuźbik, 2016, pp. 91-100). Figure 1 presents key elements shaping the surroundings of sports organizations.

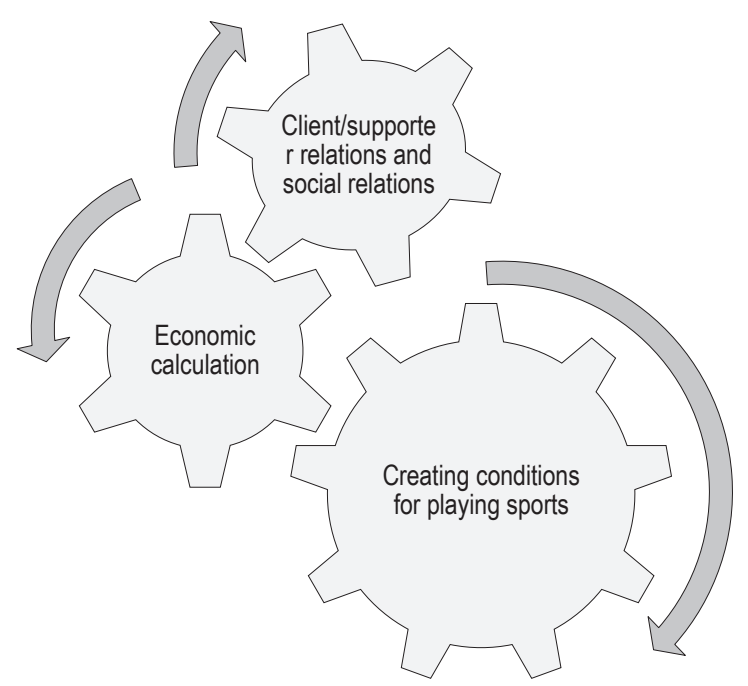

Figure 1. Elements shaping the surroundings of sports organizations

Source: own study.

It should be emphasized that between the indicated elements there must exist close relations which constitute a starting point for creating conditions for the development of a learning organization. It should be pointed out that the specificity of organizations, such as sports clubs, where the starting point is the creation of conditions for sports, allows a specialized approach to the problem of shaping relationships within the learning organization

\section{Sports club as a learning oryanization - a challenge for managers}

Taking into account the determinants and features of the learning organization, one should agree that the basic foundation here is intangible capital in the form of knowledge. But it is the managers who have the role to use it in the right way in management processes. Therefore, it is necessary to indicate the differences that allow sport club managers to build knowledge management systems aimed at transforming the club from a "traditional" organization to a learning organization. Elements differentiating the surroundings of a traditional business organization from sports organization are (Sznajder, 2008, p. 61):

1. Sports organizations operate on the sports market on the supply side and are strongly diversified (objectives, legal form, organizational structure, scope of activity, relevance to the whole sport, decisionmaking methods, etc.).

2. The goals of a sports organization (Foster, Greyser, Walsh 2006, p. 8) are more diverse than the goals of enterprises operating in other industries (sports score, financial profit, satisfaction with trophies, local community integration, social mission, etc.). 
3. Decisions of the governing bodies of sports organizations are quickly commented on by the media and fans.

4. Professional clubs on the one hand compete with each other, and on the other are dependent on each other (player transfers, exchange of experience and technology, sports score, infrastructure, finance).

5. The sports market is regulated. This means that clubs that are commercial law companies must respect not only generally applicable regulations, but also specific rules regarding sport (Sports Act in Poland, regulations of Polish Sports Associations, Regulations of national companies managing professional leagues, international regulations established by UEFA and FIFA, IOC, etc.).

6. The sports market is doubly dual. Clubs operate simultaneously on the sports market as well as on the advertising and sponsoring market. Sales take place on the primary market (sports spectacle) and on the secondary market (sale of a sports product through the media, other economic activity).

7. Products offered by clubs vary depending on whether they are offered to consumers (sports spectacle, club souvenirs, products resulting from additional business activities, etc.) or institutional buyers (television and image rights, etc.).

In addition, it is also worth adding the following aspects (Waśkowski, 2015):

1. Sport is by nature an activity based on physical activity, so from a marketing point of view it is an intangible and subjectively assessed product, and consumers (viewers or participants) buy impressions.

2. Sport evokes a strong emotional experience among consumers, strengthens personal ties because it is mostly consumed in public. In addition, it is a universal medium of communication and refers to all sections of life (geographical, demographic, cultural, economic, religious, political, etc.).

3. The result of sports competition is unpredictable and the competition cannot be repeated. This means that the sports organization manager cannot provide consumers with a specific effect, both in the form of the outcome of the game and its level. This has important consequences in the process of quality assurance of services provided.

In connection with the above-presented specificity of the market and the environment of the sports club, it becomes necessary to implement a management system that is able to react appropriately to this specificity and draw conclusions for the future. As Alberto Lozano Platonoff writes, in this situation the essence is building such a management model, which would not only be compatible with the expectations of a wide group of stakeholders and build for them value in the long term, but above all which would learn to listen and respond properly, that is learn to understand the surroundings and react in the right way, often in real time.

Management in this sense should, therefore, be dynamic in nature, i.e. it is an integrated process based on collections of synthetic knowledge about the organization and its environment, along with the method of their continuous updating and improvement enabling decision makers to give direction on an on-going basis to the organization towards the best fulfilment of short-, medium- and long-term expectations of stakeholders (Platonoff, 2009, p. 40).

As a consequence, the activities of the club, and thus the managerial staff, should be focused on the following activities (Platonoff, p. 43):

- implementation of an appropriate value system,

- striving to make the effects of functioning of the club measurable, because only what is measurable can be thoroughly analyzed and the reasons for success or failure can be indicated, 
- maintaining at the same time a high degree of organization stability (sorting out information, tasks and activities) and flexibility in order to quickly make strategic adjustments in the organization's activities,

- treating dynamic management as a process of continuous learning,

- development of an individual system of measures for the strategic development of the organization,

- creating a climate of co-responsibility of the club's participants for its development,

- creating an atmosphere conducive to continuous learning, openness to ideas, creativity,

- delegation and expecting individual responsibility for decisions and effects of actions taken,

- determining the added value of each club participant in its development and treating it as the basis of the incentive system,

- developing the evaluation system in the perspective of the interdependence of all participants and teams (departments, sections) in creating the added value of the club,

- creating conditions for cooperation at particular levels of management.

Analyzes carried out by the author show that employees of sports clubs are not focused on self-development or it is not supported by the management. Employees are often expected to undertake little-complex tasks aimed at achieving operational goals, without a clear focus on the process of drawing conclusions and improving themselves, and consequently the organization as a whole. Meanwhile, the manager's role should be to treat team members as "independent business units", create conditions for extending the competencies of team members, promote complementarity of partners' competencies in the chain of value creation, and eliminate contradictions at the interface between the organization's goal and individual goals (Jabłoński, 2015, p. 64).

In a sports club heading towards a learning, and consequently, intelligent organization, the manager's tasks should first and foremost include the role of auditor of employee competencies, so as to make a proper verification of the actual knowledge possessed by the employees. The next step is to take on the right leadership role. The manager's role is not to create the right number of rules for the organization, but to make sure that people create their own rules together. He is not a game designer and does not have to deal with low-level rules of the game. He configures high-level parameters such as diversity of team members, information flows between people and maintaining communication between teams (Appelo, 2016, p. 155). Equally important is the role of the information

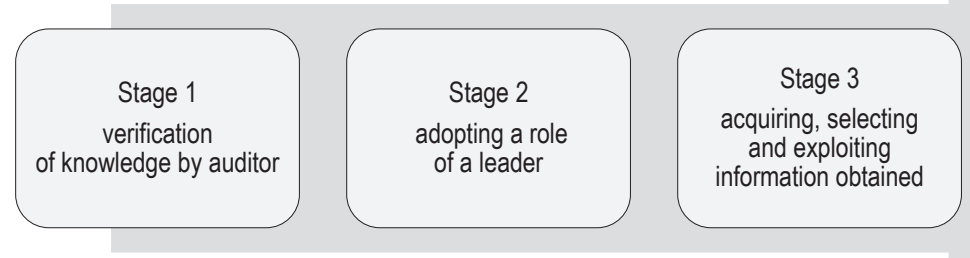

Stage 4

implementing an idea of learning organization

Figure 2. Model of development of sports club into learning organization

Source: own study. 
seeker. It is important for the manager to properly acquire, select and exploit the information obtained. Only then he will be ready to build the right organizational culture focused on the learning process, and to motivate the employees themselves to adopt an attitude of "open mind." And finally, it becomes important that the manager himself is ready to take the role of an initiator, involved in the process of implementing the assumed idea of a learning organization. The individual stages, crucial for the development of a sports club into a learning organization, are shown in Figure 2.

\section{Conclusions}

Sports clubs in Poland, wanting to develop and become more and more competitive, cannot be based only on material resources. The past and present of this type of organization clearly show that this chosen direction is fatal. Contemporary, modern sports organizations must learn to draw on intangible resources such as knowledge gathered among employees and management, resources and technological capabilities, the experience of the whole organization or specific partners - stakeholders ready to support the club at every organizational level. The ability to respond to environmental stimuli, often in real time, will distinguish these organizations from others and make them more competitive and more attractive for the benefit of all stakeholders and the entire sports industry.

\section{Refépencess}

Appelo, J., (2016), Zarządzanie 3.0. Kierowanie zespołami z wykorzystaniem metodyk Agile, Wyd. Helion, Warszawa.

Budziewicz-Guźlecka, A. (2014). Rola działalności naukowo-badawczej w rozwoju gospodarki opartej na wiedzy. Zeszyty Naukowe Uniwersytetu Szczecińskiego. Ekonomiczne Problemy Usług, (112, T. 1 Nowa gospodarka-spojrzenie interdyscyplinarne.), 9-17.

Budziewicz-Guźlecka, A., Drab-Kurowska, A. (2009). Zarządzanie wiedzą w dobie nowej gospodarki. Zeszyty Naukowe Uniwersytetu Szczecińskiego. Ekonomiczne Problemy Usług, 35, cz. 2, 39-51.

Burke, W.W., Noumair, D.A. (2015). Organization development: A process of learning and changing. FT Press.

Jabłoński, M. (2015). Kompetencje, a role współczesnego menedżera. In: I. Bednarska-Wnuk, J. Michalak, I. Świątek-Barylska (eds.), Zachowania organizacyjne. Organizacja jako przestrzeń kształtowania zachowań pracowników. Łódź: Wydawnictwo Ut.

Kaczmarek, B. (2012). Organizacja ucząca się jako nowa wartość firmy. Zeszyty Naukowe Uniwersytetu Szczecińskiego, 737.

Kuźbik, P. (2014). Social media and the development of corporate social responsibility in sports organizations. In: J. Reichel (ed.), CSR Trends. Beyond Business as Usual. Łódź: Centrum Strategii i Rozwoju Imapct.

Kuźbik, P. (2016). Sport jako platforma komunikacyjna w społeczeństwie informacyjnym. Zeszyty Naukowe Uniwersytetu Szczecińskiego. Ekonomiczne Problemy Usług, 123.

Mikuła, B. (2017). Transformacja przedsiębiorstwa w kierunku organizacji uczącej się. Studia Ekonomiczne, 336, 24-36.

Olszewska, B. (2013). Teoretyczne nurty dominujace w problematyce uczenia się organizacji. In: B. Olszewska, M. Czarnecki, E. Piwoni-Krzeszowska (eds.), Przedsiębiorstwo jako organizacja ucząca się. Wrocław: Wydawnictwo Uniwersytetu Ekonomicznego we Wrocławiu.

Platonoff, A.L. (2009). Zarządzanie dynamiczne. Nowe podejście do zarządzania przedsiębiorstwem. Warszawa: Difin. Schein, E.H. (2010). Organizational culture and leadership (vol. 2). John Wiley \& Sons.

Seebacher, U.G. (2002). Cyber Commerce Reframing. The End of Business Process Reengineering. Berlin-Heidelberg: Springer-Verlag.

Senge, P.M. (2014). The fifth discipline fieldbook: Strategies and tools for building a learning organization. Crown Business.

Sitko-Lutek, A. (2009). Organizacyjne uczenie się a kompetencje organizacji. In: A. Sitko-Lutek, E. Skrzypek (eds.), Organizacyjne uczenie się w rozwoju kompetencji przedsiębiorstw. Warszawa: C.H. Beck. 
Sznajder, A. (2008). Marketing sportu. Warszawa: PWE.

Waśkowski, Z. (2015). Wykorzystanie teorii interesariuszy w procesie kształtowania strategii marketingowej organizacji sportowych, Polityki Europejskie. Finanse i Marketing, 13 (62).

Cite this article aS: Drab-Kurowska, A., Kuźbik, P. (2018). Sports clubs as learning organizations - Polish model. European Journal of Service Management, 1 (25), 73-80. DOI: 10.18276/ejsm.2018.25-09. 